\title{
KOMPARASI MODEL PENEMUAN TERBIMBING DAN PEMBELAJARAN LANGSUNG TERHADAP KEMAMPUAN PEMBUKTIAN MATEMATIS
}

\author{
Jamilah $^{1)}$, Hartono ${ }^{2)}$, Utin Desy Susiaty ${ }^{3)}$ \\ 1,2,3) IKIP PGRI Pontianak \\ Email: jemiaisyah@yahoo.com ${ }^{1)}$, andra.hartono@gmail.com ${ }^{2)}$, \\ d3or4f4ty4@gmail.com ${ }^{3)}$
}

\begin{abstract}
The aims of this study were to investigate: (1) in indicator 1, which provides better mathematical proofing capability, guided discovery model or direct learning; (2) in indicator 2, which provides better mathematical proofing capabilities, guided discovery models or direct learning; (3) which provides better mathematical proofing capabilities, guided discovery models or direct learning. This research is a quantitative with the population of all students of semester VI Mathematics Education Study Program IKIP PGRI Pontianak. Sampling was done by cluster random sampling technique. Data collection techniques are measurement. Test the research hypothesis using $t$ test. Based on these results it can be concluded as follows. (1) In indicator 1, mathematical proofing ability with guided discovery model is not better than direct learning. (2) In indicator 2, mathematical proof capability with guided discovery model is not better than direct learning. (3) The ability of mathematical proof with guided discovery model is not better than direct learning.
\end{abstract}

Keywords: Guided discovery model, direct learning, mathematical proof capability

\section{PENDAHULUAN}

Struktur Aljabar merupakan salah satu mata kuliah wajib yang harus ditempuh oleh mahasiswa Program Studi Pendidikan Matematika selaku calon guru. Dikatakan sebagai mata kuliah wajib, dikarenakan konsep dari materi ini menjadi konsep dasar yang akan diajarkan di sekolah mulai dari Tingkat Sekolah Dasar hingga Tingkat Sekolah Menengah. Namun, materi dari Struktur Aljabar seringkali menjadi materi yang dinilai sulit oleh mahasiswa. Hal ini terlihat dari hasil Ujian Tengah Semester maupun Ujian Akhir Semester yang menunjukkan hasil bahwa tidak lebih dari 50\% mahasiswa yang memperoleh nilai diatas 50. Ini berarti bahwa pemahaman mahasiswa terhadap materi tersbut masih rendah. Kesulitan ini dinilai karena: (1) mata kuliah ini memuat konsep-konsep dasar dari aljabar yang bersifat abstrak, (2) banyak contohcontoh yang belum dikenali dengan baik oleh mahasiswa, dan (3) banyak mahasiswa yang belum terbiasa dengan pembuktian deduktif (Arnawa, 2009: 62). Padahal sangat disadari bahwa Struktur Aljabar yang sarat dengan definisi, teorema, dan lemma menuntut mahasiswa untuk memiliki keterampilan dalam hal pembuktian. Sehingga dengan memiliki kemampuan pembuktian ini, pemahaman mahasiswa terhadap materi Struktur Aljabar semakin meningkat pula. Hal ini sejalan dengan pendapat yang dikemukakan oleh Hana (Arnawa, 2009: 62) yang menyatakan bahwa pemahaman matematis dapat ditunjukkan dengan kemampuan pembuktian matematis.

Mahasiswa dikatakan memiliki kemampuan pembuktian matematis, jika 
mahasiswa tersebut mampu dalam memvalidasi atau mengkritisi bukti dan mengkonstruksi bukti yang berhubungan dengan jenis-jenis pembuktian yang sering muncul (Fadillah dan Jamilah, 2016: 106). Menurut Selden dan Selden (2007: 1-2), kegiatan memvalidasi bukti meliputi: (1) membaca suatu pembuktian dalam matematika untuk menentukan kebenaran atau kekeliruannya dengan melihat kesesuaian antara sistem aksioma, premis, dan hasil-hasil matematika yang sudah ada dengan alur penalaran deduktifnya, (2) melengkapi pembuktian (bila ditemukan ada kekeliruan), dan (3) membandingkan keefektifan bukti yang satu dengan bukti yang lainnya.

Pada penelitian sebelumnya, telah dilakukan suatu upaya untuk meningkatkan kemampuan pembuktian matematis melalui pengembangan buku ajar yang berbasis pengembangan kemampuan pembuktian matematis. Perlunya pengembangan bahan ajar tersebut sesuai dengan pernyataan Fadillah dan Jamilah (2016: 107) yang mengemukakan bahwa untuk membuat proses pembelajaran yang memfasilitasi proses konstruksi dan rekonstruksi pemahaman mahasiswa diperlukan sebuah bahan ajar yang mendukung pengembangan kemampuan pembuktian matematis mahasiswa. Namun, setelah diamati hasil penelitian terdahulu menunjukkan bahwa buku ajar saja dinilai belum cukup untuk meningkatkan kemampuan pembuktian matematis mahasiswa. Hasil penelitian tersebut menunjukkan bahwa penggunaan bahan ajar hanya dapat mengembangkan kemampuan pembuktian matematis sebesar 18,84\% dengan kategori rendah (Fadillah dan Jamilah, 2016: 110).

Kurang efektifnya penggunaan bahan ajar dalam mengembangkan kemampuan pembuktian matematis dinilai karena penggunaan bahan ajar juga perlu didukung oleh model pembelajaran yang sesuai, yakni model pembelajaran yang dapat mendorong mahasiswa untuk lebih aktif dalam membuktikan suatu pernyataan dan tentunya dengan bimbingan dosen. Selden dan Selden (2007: 1-2) dalam pernyataannya juga merekomendasikan adanya pembelajaran melalui sejumlah pernyataan dan mahasiswa diminta untuk membuktikan pernyataan tersebut. Sehingga hal tersebut memberikan pengalaman berharga bagi mahasiswa untuk meningkatkan kemampuan pembuktian matematisnya. Oleh karena itu, dalam penelitian ini bertujuan untuk mengembangkan kemampuan pembuktian matematis mahasiswa melalui suatu model dengan tetap menggunakan bahan ajar yang telah dibuat.

Salah satu model pembelajaran yang dinilai tepat sesuai dengan pernyataan di atas adalah model pembelajaran penemuan terbimbing, Model pembelajaran penemuan terbimbing merupakan suatu model pembelajaran yang memberikan kesempatan kepada mahasiswa untuk mengkonstruksikan pengetahuannya. Hal serupa juga dikemukakan oleh Hasibuan, dkk (2014: 39) yang mengatakan bahwa pembelajaran dengan model ini menuntut peserta didik menemukan sendiri hal baru yang berupa konsep, prinsip, prosedur, algoritma, dan semacamnya yang dipelajari, dimana pengetahuan yang diperoleh tidak melalui pemberitahuan melainkan melalui penemuannya sendiri baik sebagian maupun seluruhnya.

Dengan demikian, dalam
penelitian ini bertujuan untuk
mengembangkan kemampuan
pembuktian matematis melalui model
penemuan terbimbing berbantuan bahan


ajar. Namun, untuk melihat seberapa besar pengaruh penerapan model pembelajaran penemuan terbimbing dalam mengembangkan kemampuan pembuktian matematis, maka akan membandingkan kemampuan pembuktian matematis mahasiswa setelah diberikan pembelajaran dengan menggunakan model penemuan terbimbing berbantuan bahan ajar dengan kemampuan pembuktian matematis setelah diberi pembelajaran dengan model pembelajaran biasa, namun tetap menggunakan bahan ajar yang sama.

Tujuan penelitian ini adalah untuk mengembangkan kemampuan pembuktian matematis mahasiswa pada mata materi Struktur Aljabar melalui penerapan model pembelajaran penemuan terbimbing berbantuan Bahan Ajar. Secara lebih rinci, penelitian ini bertujuan untuk mengetahui pengaruh model penemuan terbimbing terhadap kemampuan pembuktian matematis dengan membandingkan antara kemampuan pembuktian matematis pada mahasiswa yang diberi pembelajaran menggunakan model penemuan terbimbing berbantuan bahan ajar dan kemampuan pembuktian matematis mahasiswa yang diberi model pembelajaran biasa berbantuan bahan ajar.

\section{METODE PENELITIAN}

Penelitian ini dilaksanakan pada Tahun Akademik 2016/2017 semester genap atau bersamaan dengan pelaksanaan mata kuliah Struktur Aljabar pada Program Studi Pendidikan Matematika IKIP PGRI Pontianak. Penelitian ini merupakan penelitian kuantitatif dengan metode penelitian adalah metode eksperimen dengan bentuk penelitian adalah True Experimental Designs dan rancangan penelitian Posttest-Only Control Design
(Sugiyono, 2011: 76). Populasi dalam penelitian ini adalah semua mahasiswa Semester VI Program Studi Pendidikan Matematika IKIP PGRI Pontianak yang sedang menempuh mata kuliah Struktur Aljabar yang terdiri dari 3 kelas. Sampel yang akan dipilih hanya 2 kelas dari 3 kelas yang ada. Sampel dipilih dengan menggunakan teknik Cluster Random Sampling. Namun sebelum sampel dipilih secara acak dilakukan uji homogenitas untuk melihat kesamaan variansi populasi menggunakan uji Bartlet metode Chi-Square.

Teknik pengumpul data yang digunakan adalah teknik pengukuran. Sedangkan alat pengumpul data yang digunakan adalah tes kemampuan pembuktian matematis. Tes ini memuat soal-soal yang dirancang untuk mengetahui kemampuan pembuktian matematis mahasiswa didasarkan pada indikator pembuktian matematis yang meliputi: (1) membaca suatu pembuktian dalam matematika untuk menentukan kebenaran atau kekeliruannya dengan melihat kesesuaian antara sistem aksioma, premis, dan hasil-hasil matematika yang sudah ada dengan alur penalaran deduktifnya, (2) melengkapi pembuktian (bila ditemukan ada kekeliruan), (3) membandingkan keefektifan bukti yang satu dengan bukti yang lainnya.

Sebelum melakukan uji hipotesis dilakukan uji prasyarat uji hipotesis, yaitu uji normalitas menggunakan uji Liliefors dan uji homogenitas menggunakan uji- Bartlett. Jika diperoleh sampel berdistribusi normal dan homogen, selanjutkan melakukan uji hipotesis menggunakan uji- $t$ berdasarkan hasil tes pada masingmasing indikator pembuktian matematis dan berdasarkan hasil tes keseluruhan. 


\section{HASIL PENELITIAN DAN PEMBAHASAN}

Penelitian ini merupakan penelitian eksperimen pada dua kelas, dimana satu kelas sebagai kelas eksperimen menggunakan model pembelajaran penemuan terbimbing, sedangkan kelas lainnya sebagai kelas kontrol menggunakan model pembelajaran langsung. Pemilihan sampel penelitian dilakukan dengan menggunakan teknik cluster random sampling pada populasi yang terdiri dari 3 kelas.

Sebelum sampel penelitian dipilih secara acak, dilakukan uji homogenitas menggunakan uji Bartlet untuk melihat kesamaan variansi semua populasi. Hasil uji homogenitas menunjukkan nilai $\chi_{o b s}^{2}=5,872$ dan $\chi_{0,05 ; 2}^{2}=$ 5,991. Dengan daerah kritis $D K=$ $\left\{\chi_{\text {obs }}^{2} \mid \chi_{\text {obs }}^{2}>5,991\right\}$ mengakibatkan $H_{0}$ diterima sehingga dapat disimpulkan semua populasi homogen. Hal ini berarti bahwa sampel yaitu kelas A, B dan $\mathrm{C}$ memiiki variansi sama. Selanjutkan dilakukan pemilihan sampel secara acak dan diperolehlah 2 kelas sebagai sampel yang terdiri dari kelas A sebagai kelas eksperimen dan kelas B sebagai kelas kontrol.

Perlakuan yang diberikan pada masing-masing kelas sebanyak 9 kali pertemuan pembelajaran yang dibagi menjadi tiga bagian pembelajara, yaitu 1 kali pertemuan untuk kontrak perkuliahan, 7 kali pertemuan untuk proses pembelajaran, dan 1 kali pertemuan untuk tes akhir. Adapun materi Struktur Aljabar yang disampaikan adalah materi Operasi Biner, Definisi Grup, Grup Komutatif, Sifat-Sifat Grup, Grup Siklik, Grup Permutasi, Order Grup dan Elemen Grup. Tes akhir diberikan setelah proses pembelajaran selama 7 kali pertemuan selesai.
Hasil tes kemampuan pembuktian matematis mahasiswa menunjukkan bahwa: (1) pada kelas eksperimen diperoleh total nilai 50 dengan nilai masing-masing indikator pembuktian matematis adalah 37 dan 13; (2) pada kelas kontrol diperoleh total nilai 36 dengan nilai masing-masing indikator pembuktian matematis adalah 24 dan 12. Hasil tes kemampuan pembuktian matematis tersebut menunjukkan bahwa total nilai yang diperoleh pada kelas eksperimen sebesar 50 dari 100 untuk nilai keseluruhan dengan rincian nilai sebesar 37 untuk indikator mengkonstruksi bukti dan sebesar 13 untuk indikator memvalidasi bukti. Sedangkan pada kelas kontrol diperoleh nilai sebesar 37 dari 100 dengan rincian nilai sebesar 24 untuk indikator mengkonstruksi bukti dan sebesar 12 untuk indikator memvalidasi bukti.

Selanjutnya untuk melihat apakah kemampuan pembuktian matematis mahasiswa setelah diberikan pembelajaran menggunakan model penemuan terbimbing lebih baik daripada kemampuan pembuktian matematis mahasiswa setelah diberikan pembelajaran menggunakan model pembelajaran langsung, maka dilakukan uji hipotesis menggunakan uji statistik yaitu uji-t. Namun sebelum melakukan uji hipotesis dilakukan uji prasyarat uji hipotesis meliputi uji normalitas pada masing-masing kelas (kelas eksperimen dan kelas kontrol) menggunakan uji Liliefors. Sedangkan uji homogentitas pada kedua kelas menggunakan ujiBartlett.

Adapun hasil uji normalitas dan uji homogenitas pada kelas eksperimen dan kelas kontrol adalah sebagai berikut: (1) pada kelas eksperimen diperoleh $L_{o b s}=0,1563$ dan $L_{0,05 ; 32}=$ 0,1566 dengan daerah kritis $D K=$ $\left\{L_{\text {obs }} \mid L_{\text {obs }}>0,1566\right\}$ mengakibatkan $H_{0}$ diterima sehingga dapat disimpulkan 
sampel berdistribusi normal; (2) pada kelas kontrol diperoleh $L_{o b s}=0,1543$ dan $L_{0,05 ; 29}=0,1610$ dengan daerah kritis $\quad D K=\left\{L_{\text {obs }} \mid L_{\text {obs }}>0,1610\right\}$ mengakibatkan $H_{0}$ diterima sehingga dapat disimpulkan sampel berdistribusi normal; (3) hasil uji homogenitas diperoleh $F_{o b s}=1,20$ dan $F_{0,05 ; 31,28}=$ 1,84 dengan daerah kritis $D K=$ $\left\{F_{\text {obs }} \mid F_{\text {obs }}>1,84\right\}$ mengakibatkan $H_{0}$ diterima sehingga dapat disimpulkan semua variansi populasi sama (homogen). Hasil tersebut menunjukkan bahwa kedua kelas berdistribusi normal dan homogen. Ini berarti uji prasyarat uji hipotesis terpenuhi terpenuhi. Sehingga analisis uji- $t$ dapat dilakukan.

Uji hipotesis dilakukan dalam dua tahap, yaitu (1) uji hipotesis pada data hasil tes masing-masing indikator untuk melihat apakah pada masing-masing indikator, kemampuan pembuktian matematis mahasiswa setelah diberikan pembelajaran menggunakan model penemuan terbimbing lebih baik dari pada setelah diberikan pembelajaran menggunakan model pembelajaran langsung, dan (2) uji hipotesis pada data hasil tes keseluruhan untuk melihat secara keseluruhan apakah kemampuan pembuktian matematis mahasiswa setelah diberikan pembelajaran menggunakan model penemuan terbimbing lebih baik dari pada setelah diberikan pembelajaan menggunakan model pembelajaran langsung.

Hasil uji hipotesis pada hasil tes indikator 1 menunjukkan bahwa $t_{\text {obs }}=0,651 \quad$ dan $\quad t_{0,05 ; 59}=1,645$ dengan daerah kritis $D K=$ $\left\{t_{o b s} \mid t_{o b s}>1,645\right\}$ mengakibatkan $H_{0}$ diterima sehingga dapat disimpulkan kemampuan pembuktian matematis mahasiswa pada indikator mengkonstruksi bukti setelah diberi pembelajaran menggunakan model pembelajaran penemuan terbimbing tidak lebih baik dari kemampuan pembuktian matematis mahasiswa setelah diberi pembelajaran menggunakan model pembelajaran langsung.

Hasil uji hipotesis tersebut menunjukkan bahwa kemampuan pembuktian matematis mahasiswa pada indikator mengkonstruksi bukti setelah diberi pembelajaran menggunakan model penemuan terbimbing tidak lebih baik dari kemampuan pembuktian matematis mahasiswa pada indikator mengkonstruksi bukti setelah diberikan pembelajaran menggunakan model pembelajaran langsung. Ini berarti bahwa tidak terdapat pengaruh yang signifikan dari penerapan model penemuan terbimbing terhadap kemampuan pembuktian matematis khusus pada indikator mengkonstruksi bukti. Hal ini dapat dilihat dari rata-rata hasil tes kemampuan pembuktian matematis pada indikator 1 , dimana rata-rata nilai yang diperoleh pada kelas eksperimen sebesar 37 dan rata-rata nilai yang diperoleh pada kelas kontrol sebesar 24.

Tidak terdapat perbedaan rata-rata nilai yang signifikan mengakibatkan tidak terdapat perbedaan hasil uji hipotesis yang diperoleh antara kedua kelompok kelas. Hasil uji hipotesis pada hasil tes indikator 2 yang menunjukkan bahwa $t_{o b s}=0,026$ dan $t_{0,05 ; 59}=$ 1,645 dengan daerah kritis $D K=$ $\left\{t_{\text {obs }} \mid t_{\text {obs }}>1,645\right\}$ mengakibatkan $H_{0}$ diterima sehingga dapat disimpulkan kemampuan pembuktian matematis mahasiswa pada indikator memvalidasi bukti setelah diberi pembelajaran menggunakan model pembelajaran penemuan terbimbing tidak lebih baik dari kemampuan pembuktian matematis mahasiswa setelah diberi pembelajaran menggunakan model pembelajaran langsung.

Hasil uji hipotesis tersebut menunjukkan bahwa kemampuan 
pembuktian matematis mahasiswa pada indikator memvalidasi bukti setelah diberi pembelajaran menggunakan model penemuan terbimbing tidak lebih baik dari kemampuan pembuktian matematis mahasiswa pada indikator memvalidasi bukti setelah diberikan pembelajaran menggunakan model pembelajaran langsung. Ini berarti bahwa tidak terdapat pengaruh yang signifikan dari penerapan model penemuan terbimbing terhadap kemampuan pembuktian matematis khusus pada indikator memvalidasi bukti. Hal ini dapat dilihat dari rata-rata hasil tes kemampuan pembuktian matematis pada indikator 1, dimana rata-rata nilai yang diperoleh pada kelas eksperimen sebesar 13 dan rata-rata nilai yang diperoleh pada kelas kontrol sebesar 12.

Tidak terdapat perbedaan ratarata nilai yang signifikan mengakibatkan tidak terdapat perbedaan hasil uji hipotesis yang diperoleh antara kedua kelompok kelas. Hasil uji hipotesis pada hasil tes keseluruhan diperoleh $t_{o b s}=0,246$ dan $t_{0,05 ; 59}=$ 1,645 dengan daerah kritis $D K=$ $\{t \mid t>1,645\}$ mengakibatkan $H_{0}$ diterima sehingga dapat disimpulkan kemampuan pembuktian matematis mahasiswa setelah diberi pembelajaran menggunakan model pembelajaran penemuan terbimbing tidak lebih baik dari kemampuan pembuktian matematis mahasiswa setelah diberi pembelajaran menggunakan model pembelajaran langsung.

Hasil uji hipotesis tersebut menunjukkan bahwa kemampuan pembuktian matematis mahasiswa setelah diberi pembelajaran menggunakan model penemuan terbimbing tidak lebih baik dari kemampuan pembuktian matematis mahasiswa setelah diberikan pembelajaran menggunakan model pembelajaran langsung. Ini berarti bahwa tidak terdapat pengaruh yang signifikan dari penerapan model penemuan terbimbing terhadap kemampuan pembuktian matematis. Hal ini dapat dilihat dari rata-rata hasil tes kemampuan pembuktian matematis pada indikator 1 , dimana rata-rata nilai yang diperoleh pada kelas eksperimen sebesar 50 dan rata-rata nilai yang diperoleh pada kelas kontrol sebesar 36 . Tidak terdapat perbedaan rata-rata nilai yang signifikan mengakibatkan tidak terdapat perbedaan hasil uji hipotesis yang diperoleh antara kedua kelompok kelas.

Berdasarkan hasil analisis uji hipotesis seperti pada poin (1), (2) dan (3) terlihat bahwa pembelajaran menggunakan model penemuan terbimbing belum mampu memberikan kemampuan pembuktian matematis mahasiswa yang lebih baik dari pembelajaran menggunakan model pembelajaran langsung. Jika dilihat dari rata-rata nilai tes, juga tidak menunjukkan perbedaan rata-rata nilai yang signifikan.

Tidak terdapatnya perbedaan yang signifikan antar kedua kelompok kelas dapat disebabkan oleh belum maksimalnya pelaksanaan pembelajaran, khususnya pada kelas eksperimen. Meskipun proses pembelajaran telah dilaksanakan sesuai dengan fase atau langkah pada model pembelajaran disertai dengan bantuan bahan ajar, namun hal tersebut masih dinilai kurang dalam upaya memaksimalkan hasil pembelajaran.

Berdasarkan catatan lapangan, perlu adanya suatu panduan dalam pelaksanaan pembelajaran berupa Lembar Kerja Mahasiswa (LKM). Melalui LKM ini, diharapkan mahasiswa memiliki panduan terhadap langkah-langkah apa saja yang harus dilakukan selama proses pembelajaran 
berlangsung, khususnya panduan yang akan membantu pada saat fase inkuiri (menemukan konsep).

\section{KESIMPULAN DAN SARAN}

Berdasarkan analisis data dari penelitian yang dilakukan serta mengacu pada perumusan masalah pada penelitian ini, dapat disimpulkan kemampuan pembuktian matematis mahasiswa baik secara keseluruhan maupun pada masing-masing indikator kemampuan pembuktian matematis setelah diberikan pembelajaran model penemuan terbimbing tidak lebih baik dari setelah diberikan pembelajaran menggunakan model pembelajaran langsung. Adapun nilai rata-rata kemampuan pembuktian matematis secara keseluruhan adalah 50 pada kelas eksperimen dan 36 pada kelas kontrol. Sedangkan pada masing-masing indikator diperoleh rata-rata nilai pada kelas eksperimen dan kelas kontrol berturut-turut sebesar 37 dan 24 untuk indikator mengkonstruksi bukti serta sebesar 13 dan 12 untuk indikator memvalidasi bukti.

Masih terdapatnya kelemahan dalam penelitian ini, khususnya pada saat proses pembelajaran berlangsung, maka disaarankan kepada peneliti lain atau pengampu mata kuliah yang ingin melanjutkan dalam penerapkan model penemuan terbimbing ini, hendaknya melengkapi perangkat pembelajaran dengan Lembar Kerja Mahasiswa (LKM). LKM ini diharapkan dapat membantu mahasiswa dalam mengikuti langkah-langkah pembelajaran yang dikehendaki, khususnya pada langkah penemuan konsep (inkuiri).

\section{DAFTAR PUSTAKA}

$\begin{array}{crr}\text { Arnawa, Made } & \text { I. } & 2009 . \\ \text { Mengembangkan } & \text { Kemampuan }\end{array}$

Bukti pada Aljabar Abstrak melalui Pembelajaran Berdasarkan Teori APOS. Dalam Jurnal Matematika dan Sains. Vol 6. No.2, Hal 62-68.

Fadillah, Syarifah dan Jamilah. 2016. Pengembangan Bahan Ajar Struktur Aljabar untuk Meningkatkan Kemampuan Pembuktian Matematis Mahasiswa. Dalam Jurnal Ilmiah Cakrawala Pendidikan. Vol 35 No. 1, hal 106-113.

Hasibuan, Haryani, Irwan dan Mirna. 2014. Penerapan Metode Penemuan Terbimbing pada Pembelajaran Matematika Kelas XI IPA SMAN 1 Lubuk Alung. Dalam Jurnal Pendidikan Matematika Universitas Negeri Padang. Vol.3 No.1, hal.38-44.

Selden, Annie dan Selden, John. 2007. Teaching Proving by Coordinating Aspects of Proofs with Students' Abilities. New Mexico State University: Department of Mathematical Sciences.http://math.tntech.edu/t echreports/ TR_2007_2.pdf (diunduh 21 September 2014).

Sugiyono. 2011. Metode Penelitian Pendidikan Pendekatan Kuantitatif, Kualitataif, dan R\&D. Bandung: Penerbit Alfabeta. 